\title{
1. Legal aspects of corporate governance models
}

Corporate governance theory originated in 1932 with the Berle and Dodd debate arising from the separation of shareholder ownership and management control. From this debate developed the economic model of Agency theory. This fundamental debate continues today, opposing (1) the shareholder primacy model to (2) alternative models, such as the stakeholder-oriented or directors' models. Our study in this chapter devoted to the legal aspects of corporate governance will illustrate the shortcomings of both theories.

\subsection{LEGAL ASPECTS OF THE SHAREHOLDER PRIMACY MODEL}

The shareholder model emerged in the United States within a specific economic context of the rise of the 'modern corporation'. This model presents several legal shortcomings.

\subsubsection{Conceptualizing the 'Modern Corporation'}

The first developments of the shareholder model came in the wake of the second industrial revolution of the latter half of the nineteenth century in Europe and the United States with the emergence of large-scale manufacturing and a growing need for capital to build large infrastructure projects, including railroads, telegraph, and mining (Dignam and Galanis 2009; Gomez and Korine 2009). Companies carrying out these projects went 'public' greatly modifying the previous model of family- or state-owned companies which shared the same sociological environment with banks and individual investors and therefore natural and endogenous controls. The new 'public' or so-called 'anonymous' companies (sociétés anonymes) developed in the financial markets. This unparalleled trend soon led to a large and dispersed ownership base. This major development spread throughout Europe and the United States, at a different pace and manner: in Europe more gradually (Ripert 1946; Gomez and Korine 
2009) - because of banking laws (in Germany) or wage protective laws (in France) - than in the United States, where the corporate finance sector government policy and regulations strongly favoured its development (Roe 1997). In the United Kingdom, the dispersed shareholding public company became dominant in the 1970s when Stock Exchange regulations provided sufficient protection against insider trading and brought transparency and confidence to markets (Cheffins 2000). Financial capitalism emerged in order to support economically this development of large industrial firms viewed as a new type of business enterprise.

In the United States, the dominant business organization model underwent a rapid transformation from small, closely held companies, where shareholders controlled and monitored the corporation's daily activities (Gomez and Korine 2009; Wells 2010), to the birth of giant, complex industrial enterprises created by mergers of many comparatively small firms into 'single giant enterprise[s] that dominated their respective industries' (Wells 2010: 1253). The US 'modern corporation' was born, vested with its three specific characteristics: limited liability for shareholders, and legal capacity and autonomy for the company itself, shifting from a public conception of 'concession' to a private notion of incorporation (Hansmann and Kraakman 2001).

The favourable regulatory context for financial markets took a disturbing turn, as the resulting structurally atomistic ownership had an unexpected impact on large corporations. Their stock being widely held by many inactive shareholders eventually led to 'loose, careless management and control' (Wells 2010: 1255). It then generated the popular sense that 'some corporations were coming under the control, not of a dominant shareholder, but of autonomous managers' (Wells 2010: 1255). There was an urgent need to tackle the problems created by the separation of ownership and control by establishing mechanisms to compel the corporation's managers, 'not only to run the corporation well but also to run it for the benefit of shareholders and not themselves' (Wells 2010: 1252). By comparison, even though the phenomenon of growth of large corporations was significant in Europe (Ripert 1946), due to the role played by banks and insurance companies and much greater concentrated shareholding it was not on the same scale and the market for industrial securities therefore remained relatively small (Gomez and Korine 2009).

The problem was not a new one in the United States, as it had previously been exposed by renowned authors who went beyond traditional legal theory to develop a new concept of the corporation (Bainbridge 2003). As far back as 1776, Adam Smith in his book An Inquiry into the Nature and Causes of the Wealth of Nations, had already raised the main issue which shaped modern corporate governance systems and 
identified the divergence of interests between managers and owners that could undermine the efficient operation of the corporation (Smith 1776, Book 5: para. 1.3.1.2):

Directors ... being the managers rather of other people's money than their own, it cannot well be expected, that they should watch over it with the same anxious vigilance with which the partners in a private copartnery frequently watch over their own ... Negligence and profusion, therefore, must always prevail, more or less, in the management of the affairs of such company.

Justice Brandeis, who tackled the same issue of the separation of ownership and control in his series of articles entitled 'Other People's Money and How the Bankers Use It', concluded that this would leave power not with a corporation's managers, but with its bankers (Wells 2010: 2157). ${ }^{1}$ He nevertheless opposed a legislation designed to break banks' power in order to prevent them from injuring the public and failed to address the management dominance/primacy. Adolf A. Berle and Gardiner Means in their seminal book published in 1932, The Modern Corporation and Private Property, best portrayed the development of dispersed ownership and the consequent ownership-control split. It is regarded as the origin of modern corporate governance, setting the agenda for corporation law for the rest of the century. Although not an easy book to read for a non-expert public (Wells 2010: 1289), ${ }^{2}$ its publication had a tremendous impact as it depicted a major element of how the fundamental transformation of the corporation affected American society and capitalism itself, namely, its enormous financial potential yet risk as evidenced by the growing hostility large corporations could inspire in the aftermath of the Great Depression. It comprehensively

1 Brandeis believed that the fundamental problem of the modern corporation was a growing separation between the corporation's managers and their firm, and not with its shareholders. This is why Brandeis opposed a legislation designed to break banks' power by prohibiting interlocking directorates, the 'Money Trust' legislation. The result of the separation of corporate management and ownership that most concerned Brandeis was the risk of giant corporations harming the public and the small proprietors that they competed against, not the shareholders.

2 The almost one hundred pages of The Modern Corporation provides a detailed synopsis of legal changes that had over decades disempowered shareholders. Relying on Means' study of growing corporate concentration, the authors asserted, there was a "centripetal attraction, which draws wealth together into aggregations of constantly increasing size" (Berle and Means, quoted by Wells 2010, 1290), that was expected to lead the two hundred largest US corporations control half the nation's corporate wealth (Wells 2010: 1290). 
highlighted three major problematic characteristics of modern corporations still relevant today in many countries: the high concentration of wealth within a small number of private organizations; the emerging investors' industry indirect and intermediate ownership; and the underlying responsibility and accountability that these companies should owe society as a whole but do not in practice (Wells 2010). The book established the separation of ownership and control as the central issue of modern corporate governance. The new conception it developed concerning the 'modern corporation' served as a foundation for the very first theory of corporate governance, the famous Agency theory, fathered by A. Berle and G. Means. Their profound insights into both the governance issues faced by these emerging modern corporations and the impact these corporate governance issues had on the public led to the success of their book, engendering endless debates on corporate governance issues since.

\subsubsection{Shareholder Primacy Model in Law and Economics Literature}

The Agency theory relies on market forces and imperfection (Coase 1937). According to the most supportive authors of the theory, Jensen and Meckling, the corporation, named the 'firm', is formed from a nexus of private contracts, whose primary purpose is to maximize shareholder wealth (Jensen and Meckling 1976): 'the firm has to be seen as a nexus of legally and institutionally enforced contracts'. Shareholders, seen as owners, establish contracts acting as principals, appoint managers as agents and give directors authority to control the company on their behalf. However, as Jensen and Meckling pointed out, conflicts of interests between the principals and the agents occur when managers act in their own self-interest by extracting benefits from the company. Such opportunistic behaviour results in agency costs to the company, which include losses in corporate value to the principals. The key governance is therefore how best to persuade managers to behave fairly on behalf of investors, avoiding discretionary opportunistic behaviour by managers. Essential to the theory is the existence of informational asymmetries between managers and shareholders. Such asymmetries affect the behaviour of corporate actors and lead to agency problems, principally investors' ability to effectively monitor management, ensuring it protects their interests.

To find a better balance of powers among the various organs of a company, reduce agency costs and provide more protection for shareholders against managers, governance policies advocating shareholder supremacy in corporate decision-making was legitimated. Here, corporate 
governance is concerned with ways of aligning investors' and managers' interests, thus ensuring that firms are run for the benefit of investors only. Greater transparency is essential to effect this realignment. Economic theory reactivated the old debates on the nature of the corporation, in the specific context of the dispersion of ownership. It considered that the corporation was composed of a nexus of contracts, with managements' main goal being to pursue profit maximization. The very purpose and scope of corporate governance was viewed as purely restrictive to reduce agency costs between shareholders and managers, implying that the corporate and shareholders' interests were viewed as identical. Other interests, such as those of employees, creditors, suppliers and other third parties, were not appropriate in corporate governance as they were meant to be protected through other channels, such as specific contractual or regulatory regulation.

Agency theory became the 'dominant ideology' (Hansmann and Kraakman 2001: 14) in the United States and became widespread worldwide, probably due to its unrivaled success at the time. Yet, problems arose especially outside the United States, due to legal differences, cultural misunderstandings and a narrower approach to factual contexts than in the United States. Indeed, Agency theory is based on a set of hypotheses which largely neglect the legal framework and the institutional context in which corporate governance systems operate.

\subsubsection{Legal Shortcomings of the Shareholder Primacy Model}

\section{(a) Shareholders are not owners of the company}

First, economic and financial doctrines rely on the hypothetical basis that shareholders are 'owners' of the company, arguing that, consequently, corporate governance should enhance protection of shareholders' rights and assign firms' objectives to maximize shareholders' values. The 'owner' status of shareholders in the firm is a misuse of legal concepts. It is not accurate to maintain that a shareholder's legal right over the corporation is that of an owner. Rather, the shareholder owns a number of shares issued by the company and assumes a proportionate risk in the capital. Shareholders are therefore considered as ordinary unsecured creditors, with the interest of 'residual claimants'. Their interest is last in right because all other creditors have the right to recover funds from the company prior to the shareholder receiving any part of any profits (Magnier and Rosenblum 2014). Eisenberg was among the first US scholars to assert that analogizing shareholding from proprietary concepts was highly questionable (Eisenberg 1989 and 1999) and authors in Europe assert the same (Dignam and Galanis 2009; Germain and 
Magnier 2017). Bainbridge confirmed that proposing an analogy between shareholders and owners looked like a 'reification' fallacy (Bainbridge 2003). Assessing that the company is run for the sole interest of the shareholders is misguided.

\section{(b) Potential conflicts of interests are ignored}

Be it majority or minority, all shareholders should be legally treated equally. In listed companies though, the variety of structural ownership appears to be a prominent criterion in the differences in corporate governance systems worldwide (Tirole 2005). Whereas in some countries corporations are diffusely owned with managers firmly in control, in other countries corporations have kept a concentrated ownership (Bebchuk and Roe 1999). These major differences between capital structures in large public companies can be explained by historical reasons and a differentiated approach to economic policies (Albert 1991; Magnier 1999; Roe 2006; Pierre 2013: 16). The shareholder's protection argument as developed by the shareholder primacy doctrine does not take account of these differences. It relies on specific ownership assumptions, and only addresses the specific challenges encountered by large, publicly listed corporations run by professional managers and owned by widely dispersed shareholders observed in the US modern corporation in the 1930s (Bebchuk and Roe 1999) and, later, in the United Kingdom (Cheffins 2000). The shareholder model exclusively addresses the conflict between shareholders and managers and strives to align two sets of interests through greater transparency (reports) or incentives (stock options). The conflicts of interests which arise in many jurisdictions with concentrated share ownership are of a different nature as they arise from the power of certain controlling shareholders over minority shareholders not from that of a managing group over shareholders.

This brings about alternative agency problems, which are not identified by the classic agency theory. Notably, conflicts may occur between certain groups of shareholders, namely, between majority (controlling) shareholders and minority (non-controlling) shareholders. ${ }^{3}$ In many

3 In Germany, for example, when family ownership began to be less common and a new capitalist structure arose in the 1920s, "the major conflicts of interest within firms, while the interests of controlling shareholder typically coincide with that of the "business in itself", were the one between large shareholders and transient investors' (Hansmann 1996). Following the Second World War, due to the entrenchment of large shareholders (increasing divergence from the one-share-one-vote principle), new conflicts of interests occurred between majority and minority shareholders. 
cases, majority controlling shareholders may monitor managers effectively and dominate the boards. In this instance, the interests of minority shareholders are aligned with the controlling shareholders: the majority shares are at stake while the minority shareholders are not thoroughly sacrificed. This is not the case when there is a highly significant disconnect between control rights and control in capital, a pattern which is frequently experienced in transition economies (see Part III), for example, in Taiwanese firms, Japanese Kereitsu or Korean chaebols (Ryo-Hon Koh 2015). When such a deviation between the interests of controlling shareholders and those of minority shareholders occurs, with no big risk at stake for the controllers, minority shareholders may suffer. Highly controversial conflicts of interests between controllers and minority shareholders which may thus arise need to be addressed. Taking the variety of structural ownership criteria into account highlights the major differences in corporate governance systems worldwide and reveals how narrow are the premises of the shareholder primacy theory, taking no account of other stakeholders.

Accordingly, the shareholder primacy model relies on the belief that the sole purpose of corporate governance is to help a listed company to maximize shareholder value. In so doing it disregards corporate governance realities in other markets in the world where various types of 'insider' systems of governance exist within companies' concentrated ownership. These insider systems are thought to be more representative of continental European and main Asian corporate jurisdictions. In a comparative corporate governance perspective, the dominant economic theory therefore fails to take into account many other existing structures of ownership (Celik and Isaksson 2013). These varying capital structures have a major impact on corporate governance issues and may result in conflicts of interests of a different nature.

An additional shortcoming of the shareholder theory results from the assumption that all investors act similarly. As currently acknowledged, the types and strategies of investors depend on a more or less coordinated market economy (Pierre 2013) and financial legal context (Roe 2006), as shown by the significant differences between US and UK corporate governance systems, and even greater differences between AngloAmerican and German, French or Japanese (Aoki 1990) models. Investors' strategies may be long term or short term, and, in the case of hedge funds, very short term (Celik and Isaksson 2013). Accordingly, shareholders' interests vary from one type to another and this makes it impossible to determine the shareholders' interests. A last factor that should be taken into consideration is the recent evolutions in shareholdings, leading to new blocks of shareholders. Internationalization and 
professionalization trends allow new large blockholders of institutional investors to influence the boards of large public companies (Bainbridge 2003; Vasudev in Vasudev and Watson 2012). This new pattern brings new conflicts of interests which these corporate governance systems have to deal with: individual dispersed shareholders do not have the same 'voice' in the company as large professional blockholders. In recent years, an increase in the activism of institutional shareholders has occurred in the United States and Europe. In spite of a new resistance to the powerful forces of short-termism afflicting corporate behaviours, many companies continue to return excess cash to shareholders, at the expense of value-creating investment. The shareholder primacy seems to be an 'ideology' rather than a scientific model (Eccles et al. 2014: 2).

\section{(c) The company as a separate entity is disregarded}

A third major shortcoming addresses the nature of the company. According to the agent theory, the corporation is composed of a nexus of contracts and run in order to maximize the value of shares in the sole interest of shareholders. Putting the emphasis on the market, in assuming that a corporation is just like any type of other agent on the market, economists miss the crucial point that corporations gained a new status through registration laws and are legal entities separate from their shareholders. The agent theory fails to take into account this particular dimension. The traditional debates on the legal nature of companies help explain this particular dimension.

The origins of the company, both in their historical and legal acceptations, are a relevant matter to be addressed, as they have significant implications for recent corporate governance developments. This is mainly true with respect to the major issues and controversies regarding companies, including how to understand the 'true' nature of the company and its role in society. Among all controversies in company law, that of the proper 'nature of the company', being alternatively qualified as a fiction, an aggregate, an autonomous or a real person, has proven to be the most fundamental and enduring ones (Dignam and Galanis 2009; Germain and Magnier 2017). This controversy refers to major issues such as: Who owns the company and who has control over it? In whose interest is that control to be exercised? What is a company's objective? Similarly, corporate ownership, the source and scope of powers of the boards, and the appropriate deference to their decisions remains central to the current debates on corporate governance.

Many hesitations come from the ambiguous dual nature of companies, legally originating from a contractual agreement between shareholders, while, at the same time, being qualified as legal persons - at least as soon 
as they have publicly registered themselves as companies. This duality is one theoretical obstacle that deserves specific attention. The notion of corporation as a contract goes as far back as Roman law. In Roman times, the legal form societas gradually developed. This form was progressively given a specific definition, being distinguished from various types of similar or comparable (co-ownership) agreements, with a common purpose as a key determinant. It differentiated itself from the so-called 'consortium' or 'association' forms that represented a group of close relatives having inherited from, for example, the pater familias. Throughout the Middle Ages, this definition was sharpened and refined with the creation of the first unlimited liability commercial companies. During the nineteenth century, the corporation's contractual dimension was strongly favoured, as the company objective perfectly matched the prevailing principle of a party's autonomy of will, and was progressively embedded in written Articles of Association as proof of this contractual dimension of companies. Statutes attached to this philosophy of party autonomy still refer to the origins to provide a contractual definition to companies.

While the contractual argument properly applies to small partnerships or companies with unlimited liability it is inappropriate in defining the legal nature of limited liability corporations. This became especially true of the large companies with hundreds or thousands of shareholders. In parallel with the emergence of the common law partnership, the civil law société en commandite in France and the German 'common ownership' (Gesamte Hand), academic views on the nature of the corporation evolved significantly, as 'collective ownership' appeared incompatible with the contractual analysis of Roman and pre-modern law. ${ }^{4}$ Publiclyowned limited-liability companies (public companies in the United Kingdom, Aktiengesellschaft in Germany or société anonyme in France (Ripert 1946)) whose shareholders were involved in the activity of the company were appropriate legal frameworks for companies. The contractual perspective progressively vanished which favoured the recognition of the company as an individual entity in legal doctrines throughout the world. The 'legal entity' concept, which defined a company as a person, was viewed as appropriate and dominated. The focus of the debate then

4 Companies' assets and liabilities could not be separated from the private individuals without adding a new legal person. As Dicey is commonly quoted as stating (Dewey 1926): "when a body of twenty or two thousand or two hundred thousand men bind themselves together to act in a particular way for some common purpose, they create a body which by no fiction of law but by the very nature of things, differs from the individuals of whom it is composed'. 
shifted to the legal origins of the company and its legal characteristics. The voluminous continental literature on the topic revealed misgivings and became embroiled in a bipolar debate between the company as fictitious and the opposing 'real personality' theories. The doctrine of 'fictitious personality' theory denied any social reality at all to corporate actions. Under this theory, as members of an already identifiable and socially meaningful group, shareholders were consequently highly constrained by the corporation's specific business functions and the grant of special authority via state charters to such organizations to act as legal persons was required (Dignam and Galanis 2009). The subsequent 'concession theory' mainly developed by Von Savigny, the founder of the influential 'historical school of jurisprudence' in Europe, assumed that a privilege was granted by delegation of the state to private entities to operate under the state supervision. This theory legitimized a strong role for the state in the creation of corporations. The gradual decrease of public supervision and governmental consent was soon replaced by the enactment of general incorporation laws which affected the fictitious doctrine.

On the other hand, the realist theory challenged the fictitious perspective, vesting reality in the company. In one of his most famous treatises, The German Law of Associations, Otto Von Gierke, the German medieval law historian, developed the idea that a corporation was an independent social group whose characteristics placed it between the spheres of private and public law, consistent with the prevailing freedom of commerce of public authorities. This well-known theory spread rapidly throughout Europe and was even pushed to an extreme anthropomorphism in Frederic W. Maitland's eloquent statement that a corporation could be considered 'a living organism and a real person, with body and members and a will of its own' (Maitland 1902). Without the need to go this far, Von Gierke's realist theory contributed to the spread of an institutional understanding of corporate law in Western European jurisdictions. It had a major impact and was conclusive in expanding the role of directors to defend the company's own interest per se (i.e. not limited to the sum of shareholders) and encouraged companies to endorse the fulfilment of a social goal. In addition, although institutional theories addressing the nature of corporate legal personality have been historically prominent in Germany and France, they also became known in common law countries, as Von Gierke's work was made available in England. ${ }^{5}$ The

5 Maitland translated and prefaced Gierke's Political Theories of the Middle Ages in English in 1902. 
German real entity theory of the corporation inspired numerous scholars and law-makers in France (Michoud 1899), the United Kingdom, and even in the United States, where the legal nature of the company as a legal person remained the same after the emergence of the 'modern corporation'.

Corporations should not be considered to be composed of a nexus of contracts but as legal entities. The contractual conception of the corporation with its consequent assumption that a corporation should be managed solely for its shareholders' personal interests is misguided. In its exclusive focus on shareholder value, it ignores that the evaluation of a company needs to include more than only its expected cash flows for investors. It ignores the very important concept of legal personality and of the personal 'interest of the company'. Asserting that corporate interests and shareholder interests are one and the same thing based on the argument that shareholders are 'owners' of the firm negates corporate personality, which is a key feature in legal theories of legal personality.

Once the corporation is identified as a real person, one significant normative implication lies in a potentially specific sense of the company's purpose and interest, reviving the traditional conception of corporate realism (Dignam and Galanis 2009). As opposed to the pure contractual perspective adopted by the Agency theory, where the interest of the company is no different from that of its shareholders, the real entity status of a company makes it an autonomous legal person with its own purpose and interest to be defended by its representatives.

\section{(d) Statutory directors' authority is neglected}

A last but very significant shortcoming is that the shareholder primacy model considers directors as trustees of shareholders. Berle's doctrine states that managers are trustees for the shareholders and, therefore, only accountable to them (Berle 1932). It logically follows the assumption that a corporation is run in their sole interest imposing upon corporate managers a legal obligation to maximize financial returns to shareholders. This assumption relies on the premise that the market value of the publicly-traded corporation's shares is the sole measure of performance. This assumption is not valid.

Today, authors recognize that corporate governance standards should be conducive to create value. Creating value in sustainable and profitable companies ought not be equated to the creation of 'shareholder value' only. 'Shareholder value' in the narrow sense of increasing distributable profits while adding little or no sustainable value permits the remuneration of the risk assumed by shareholders through the payment of dividends. To pose as a principle that the corporate governance should 
favour the creation of value is simply to make two assertions. First, it must ensure that the corporate bodies act in conformity with the company's interests in a sustainable manner, regardless of whether these interests completely match with the shareholders' interests. Second, it implies that the company's interest may be disconnected from the shareholders'. The creation of value requires sustainability and this is what distinguishes the company's interest from the selfish interest of a shareholder who expects from his investment a short-term gain or the payment of dividends (Paclot, in Magnier et al. 2010). Contrary to what is assumed by Agency theory supporters, maximizing shareholders' value should not be the sole purpose of the corporation. Stock price is therefore not the best measure of corporate performance (Blair 2003) which should use long-term and sustainable measurements. The role of directors, as trustees of the corporation as a whole, should be to promote true sustainable value creation. So stated, the role of the board becomes clearer: managers on boards must be the cornerstones of corporate governance. The purpose of corporate governance ought to be to lead directors to ensure compliance with the sustainable interest of the corporation and its stakeholders. Corporate governance recommendations should be solely designed to achieve this purpose (Paclot, in Magnier et al. 2010).

In listed companies, directors derive their corporate powers from corporate national statutes and they are trustees to the company itself. Contrary to what is assumed by Agency theory supporters, a board's powers do not originate from a contractual source but from their legal basis as a 'collegial body' with the broadest powers to manage and represent the company, except when the law gives power to another corporate organ (principally, the general meeting). ${ }^{6}$ Similarly, their responsibility derives from the law which subjects them to liability for conduct that harms not just shareholders, but the corporate coalition as a whole. According to this approach, corporate law comes closer to requiring 'director primacy' rather than shareholder primacy (Blair and Stout 1999; Bainbridge 2005; Blair 2003). Accordingly, directors should not be considered as trustees or agents of shareholders but as trustees of the company as a whole.

Agency theory assumes that the ideal shareholder will play a superior role in corporate governance. In practice, this 'ideal' was never realized.

6 For example, in UK company law and in the British Commonwealth, 'the powers of directors in UK company law are original and un-delegated' (Vasudev, in Vasudev and Watson 2012: 8). In France, whereas a hierarchy exists between the two organs, there is no possibility for the one (shareholder meeting) to infringe upon the board's statutory power (Motte case, 1946). 
Rather, as corporate realism theory provides, managers have to play the leading role in corporations (Dignam and Galanis 2009). Alternative models are the second contribution of legal theory to corporate governance. Having a broad conception of the company's goal, they take consideration of the role of the company in society at large and principally assume and provide an extensive managerial power in the operations of the corporation.

\subsection{LEGAL ASPECTS OF CORPORATE GOVERNANCE ALTERNATIVE MODELS}

\subsubsection{Dodd's Premises}

At the same time as A. Berle and G. Means started elaborating the foundations of what would later be known as the economic model of Agency theory, a debate took place between A. Berle and E. Dodd. This debate focused on the role of the corporate managers, more precisely on whether and on what ground they should be held accountable to other stakeholders. ${ }^{7}$ In order to answer this question, E. Dodd followed a novel pluralist approach guided by the basic insight that large companies were real entities, distinct from their shareholders and, as other real persons, were vested with a social role and a wider responsibility towards society as a whole:

[they] wield tremendous power and influence over the lives of all members of society, whether in providing goods, services or employment, and accordingly, with this power comes the responsibility to act in the wider interests of society. (Zhon Xing Tan 2014)

Pursuant to Dodd's doctrine, managers were trustees for the corporation as a whole and, therefore, accountable to stakeholders within and even outside the company (Dodd 1935).

Dodd reactivated the age-old autonomous entity theory, pointing out both companies' specific interest and their social role. Opposing the

7 E. Dodd accepted that the corporation is a real entity, distinct from its shareholders, has a social role and should be subjected to the principles of citizenship. In the case of corporate citizens, purely economic self-interest, i.e. profit maximization, may be subjected to other social objectives. In a realistic view, since managers had to discharge their duties in accordance with the entity that is distinct from its shareholders, they should also be expected to have a sense of responsibility toward employees, consumers, and the general public. 
shareholder-centric approach, he was the first to argue that the role of managers was to protect the interests of the company itself and not solely those of shareholders. Accordingly, managers were vested with considerable discretion in defending the corporation's interests, along with a large degree of independence and deference to the choices they made (Gelter 2011).

\subsubsection{Stakeholder Variants}

Following up on these first stages, a new trend of models emerged in the United States starting in the 1970s, with all actors arguing in favour of a pluralist vision of managers' role. These various models had in common the fact that they allowed managers to balance all stakeholders' interests and not solely profit maximization under the pressure of shareholders' expectations. Subsequent theories focused mainly on the status to be given to stakeholders other than shareholders within the company. The argument that the firm is composed of numerous actors all contributing to its economic performance and value, who should all be rewarded adequately, was revisited in this stakeholder perspective (Blair and Stout 1999; Millon, in Vasudev and Watson 2012). Other alternatives were proposed to the maximization of shareholder value promoted by the Agency theory. With subtle variations, these theories claim that shareholders cannot be considered the sole residual claimants ${ }^{8}$ and that other stakeholders should be considered as a group to whom management need to be responsive.

A major contribution to stakeholder theory in the tradition of E. Dodd came from the Communitarian model promoted by M. Blair and L. Stout in the mid-1990s (Blair and Stout 1999; Blair 2003; Stout, in Vasudev and Watson 2012; Millon, in Vasudev and Watson 2012). Comprised as a 'team' with a common goal of productivity, business corporations should elect directors with the duty to ensure equity in the distribution of the corporate wealth among the different stakeholders. They would play a central role as 'mediating hierarchs'. Regulation should favour directors who serve not only shareholders' interests, but also those of employees, consumers, creditors, and other corporate 'stakeholders'.

8 Hansmann (1996) shows that stock maximization may not be in the best interests of shareholders. 


\subsubsection{CSR Integration into Corporate Governance Standards}

Taking the expansion of corporate responsibility to the most advanced level, the latest series of organization theories promote sustainable corporate social responsibility (CSR) that places corporations in their broader social and environmental context (environmental, social and governance (ESG)). Business organizations operating on religious and moral principles, as exemplified by successful philanthropic or paternalistic engagements, such as those of Quakers entrepreneurs in the eighteenth and nineteenth century in the United States, have long existed in practice. ${ }^{9}$ CSR goes even further.

Social responsibility was first formally discussed by Bowen (Bowen 1953), in his seminal book Social Responsibilities of the Businessman. At that time, CSR was addressing individuals and was referred to as 'the obligations of businessmen to follow the objectives and values of society and produce social goods beside economic goods'. Shortly afterwards, the CSR concept was integrated into general systems theory by Boulding (1953), who argued that business organizations should be vested with broader responsibility, including outsourcing, environmental and social protection. Friedman defined CSR as:

clearly articulated and communicated policies and practices of corporations that reflect business responsibility for some of the wider societal good. Yet the precise manifestation and direction of the responsibility lie at the discretion of the corporation. CSR is therefore differentiated from business fulfillment of core profit-making responsibility and from the social responsibilities of government. (Friedman 1970; and see Matten and Moore 2008)

In the wake of the global financial crisis, renewed interest for shared value maximization has appeared, showing a shift toward a more responsible form of capitalism. In recent years, a new model, inspired by the CSR approach to management, emphasizing stakeholder balancing, but paralleling many of the arguments raised by the 'communitarian' or 'progressive' schools, has emerged. ${ }^{10}$ The so-called 'Enlightened

\footnotetext{
9 See Weber 1958; Light 2010, and the included references.

10 See e.g., Mitchell 1992 (arguing that courts should modify corporate law to grant stakeholders standing to sue directors when the former are harmed by corporate action); O'Connor 1993: 936-65 (arguing that corporate law should be changed to encourage employee representation on the board and standing to sue); see also Greenwood 1996: 1023 ('[A]ll but the communitarians agree that virtually the sole task of corporate law is to ensure that managers act as agents for the shareholder owners'); cf. Coffee 1990 (discussing the role of stakeholders
} 
Shareholder Value' supported by E. Porter (Porter 1992) is seen as a possible 'third way', an 'alternative to strict shareholder primacy and to a pluralist vision of CSR' (Millon, in Vasudev and Watson 2012: 69). The main purpose of this approach is to seek to reconcile the corporate world with society, doing well by doing good. The solution envisioned by the 'principle of shared value' is to create economic value which in turn generates social and societal value. This entails a long-term approach to companies' performance. The shared value main idea is to encourage corporate policies and practices that enhance the competitive advantage and profitability of the company while simultaneously advancing social and economic conditions in the communities in which it sells and operates. Consequently, shared value is not corporate social responsibility, philanthropy, or even sustainability, but a new way to achieve economic success. Based on the Enlightened Shareholder Value theory, "corporations should pursue shareholder wealth with a long-run orientation that seeks sustainable growth and profits based on responsible attention to the full range of relevant stakeholders interests' (Millon, in Vasudev and Watson 2012: 68). This approach recognizes that businesses take the blame for many of society's economic, social and environmental woes, and, in the aftermath of the global financial crisis, it seeks to 'restore public trust through a redefined vision of capitalism with the full potential to meet social needs' (Porter 1992). The principle is 'creating economic value in a way that also creates value for society by addressing its needs and challenges' (Porter 1992). Attention is given to long-term business, a long-range and sustainable conception of value and profit, thereby reconciling different expectations by setting them in the long term. Rather than seeking to balance all stakeholder interests, the aim is to seek sustainable growth for the company and its environment.

Making syntheses of existing works, Nobel Prize winner Jean Tirole suggests three ways to implement CSR (Tirole 2016). According to the first approach, the companies adopt a vision on a more long-term basis, compatible with sustainable development. The company's sustainable vision leads to placing sustainability at the heart of the company. For example, a company may waive putting a product on the market if certain risks (pollution or public health, for example) are not controlled and are likely to be revealed on the longer term. A second form of CSR leads a company to adopt virtuous behaviour from the perspective of better

in a firm); Millon 1990: 261-2 (praising case law that reaffirms directors' discretion to consider non-shareholder interests). See generally Mitchell 1992 (surveying recent non-traditional approaches to corporate legal scholarship). 
performance. Such a prospect is not incompatible with the pursuit of profit maximization and leads to the making of trade-offs between various interests, including those of investors, employees or consumers. A third form of CSR, 'the company philanthropy' according to J. Tirole, is a purely altruistic approach without pursuit of profit. Benefits may be generated by such an approach, in terms of image and reputation. Whatever the form, a new approach to companies' performance was needed to achieve CSR objectives.

\subsubsection{Corporate Governance and Sustainable Performance}

The most controversial issue regarding CSR is its links with economic performance. Commercial, capitalist companies must be profitable to survive and be able to promote other CSR interests as well. Shareholders expect gains from their shareholding and serving the shareholders' interest therefore remains a key concern for companies worldwide. Any corporate governance system therefore needs to remain attractive for investors in order to be effective. But all depends on what is meant by performance.

The shareholder model assumes that stock price performance is the best measure of the firm's value and governance (Blair 2003). But that is not always true. First, stock price performance may be disconnected from the intrinsic firm value. Second, as the Enron case has shown, a firm may be compliant with corporate governance standards and still suffer from unethical behaviour from the top executive management. Many authors have attempted to formalize the links that may exist between attributes of corporate governance and the quality of the accounting results (Klein 2002; Peasnell et al. 2003; Niu 2006). Overall, the findings from this research are ambiguous: the relationship between an attribute of governance such as the size of the board of directors and the quality of the results may be either positive, neutral or negative depending on the context (Cormier, Ledoux and Magnan 2010). In any case, the approach to performance is short-term.

Today, authors argue that sustainability and the broader concept of social responsibility imply a change in the spirit of governance, and that companies that perform better with regard to the 'triple bottom line' can increase shareholder value while contributing to the sustainable development of the societies in which they operate. ${ }^{11}$ Considering CSR

11 See Salvioni and Gennari 2016. The main finding of this article is that sustainability and the broader concept of social responsibility imply a change in 
as core to business and generating sustainable returns over time requires a sharper focus not only on governance but also on environmental and social factors that assume a shift in the conception of performance itself (Fonbaustier and Magnier 2013).

Recently, Eccles' research studies has confirmed with quantitative data the benefits of a long-term performance approach. Harvard Business Review contributors Ioannou and Serafeim's study shows decisive and presently unchallenged results. They compared a sample of US companies (a matched sample of 180 US companies, 90 high and 90 low sustainability firms) characterized by a distinct corporate governance model $^{12}$ for an 18-year period, in order to examine issues of governance, culture and performance. They found that 'High Sustainability firms dramatically outperformed the Low Sustainability ones in terms of both stock market and accounting measures' (Ioannou and Serafeim 2014). This outperformance occurs only in the long term and the authors argue that high sustainability company policies reflect the underlying culture of these types of organizations, where environmental, social and financial performance significantly matter. These policies also forge a strong corporate culture by making explicit the values and beliefs that underlie the mission of the company. The thesis is very promising as it argues that

the spirit of governance. Corporate boards should be able to perform common goals, with attention to similar key performance indicators, such as ensuring fair disclosure or accountability. Companies that perform better with regard to the triple bottom line can increase shareholder value contributing, at the same time, to the sustainable development of the societies in which they operate.

12 The characteristics were the following: a governance structure that in addition to financial performance, accounts for the environmental and social impact of the company; a long-term approach towards maximizing inter-temporal profits; an active stakeholder management process; and more developed measurement and reporting systems. Of a panel of 180 companies, half of them had adopted 'high sustainable' policies for a long time (corporations that consider environmental and social objectives as core issues for their strategy and operations) and half had no environmental or social policy at all. The positive findings were that the group of high sustainability companies was significantly more likely to assign responsibility to the board of directors for sustainability and to form a separate board committee for sustainability. In addition, they were more likely to make executive compensation a function of environmental and social perception (including consumers' perception) data. This group was also more likely to establish a formal stakeholder engagement process where risks and opportunities were identified, with training managers in stakeholder engagement. They appeared to be more long-term oriented: they had an investor base with a larger proportion of long-term oriented investors and they communicated more long-term information to stakeholders. 
'organizations that voluntarily integrate environmental and social policies in their business model represent a fundamentally distinct type of the modern corporation' (Ioannou and Serafeim 2014), requiring greater director empowerment and accountability. Achieving a better balance between interests and promoting CSR interests is therefore not incompatible with the company's performance.

The normative implications of these new approaches are rich and various. Mainly they have the merit of putting the focus on the central role of the board in defining and protecting the company's interest and making it prevail over other private interests such as those of shareholders or other stakeholders.

Compared to the shareholder-centric theory, however, these approaches have specific legal shortcomings.

\subsubsection{Legal Shortcomings}

\section{(a) A need to specify CSR concepts}

The trouble with these models is that the concepts used are new and lack clarity. The concept of 'stakeholder' covers a wide range of meanings and is constantly evolving. The expression first appeared in management literature in an internal memorandum at the Stanford Research Institute in 1963, which became the SRI International. Originally defined as 'those groups without whose support the organization would cease to exist' (Freeman 1984), CSR promotes the view of the company and its stakeholders as a coherent and sustainable whole. The original list of stakeholders was rather short, and included a broad definition of stakeholders, such as employees, customers, suppliers, lenders and even society. The needs and concerns of all these groups should be taken into account by corporate executives, to ensure that their plans and the firm itself would be viable. It rapidly became apparent, though, that the definition was too vague and required clarification. Renowned authors such as R. Edward Freeman broadly identified stakeholders as 'any group or individual who can affect or is affected by the achievement of the organisation's objectives' (Freeman 1984). At the risk of making everyone a stakeholder, this widely used Freeman definition was developed in organizational behaviour theory and then adopted in US doctrine and management practice. ${ }^{13}$

13 For example, the Business Roundtable in the United States or, in the United Kingdom, the Watkinson Report on the Responsibilities of the British Public Company (CBI 1973). In parallel, protection of specific stakeholder 
Today, CSR is a complex multi-purpose concept which is made up of successive layers and has integrated human rights issues into corporate governance on multiple occasions (Welford 2002; Crag 2012). Its ambition is to address concerns for the environment (such as climate change, hazardous waste, nuclear energy, ecological balance, etc.); society (social diversity, human rights, consumer protection, consumer consciousness, etc.); and of course corporate governance matters (management/board structures and representation, employee relations, executive compensation, anti-corruption measures, etc.). Additionally, CSR used to be at the discretion of the company and voluntary. It was intended to be inclusive, relativist and evolutionary, and was expected to be individually applied but universally shared among organizations. In many countries, CSR standards have partially been integrated into hard law and as such are no longer primarily at the company's discretion. CSR is widely defined as 'l'ensemble des obligations, légales ou volontaires, qu'une entreprise doit assumer afin de passer pour un modèle imitable de bonne citoyenneté dans un milieu donné' (Pasquero, in Gendron and Girard 2013: 48)..$^{14}$

\section{(b) A high potential for dilution of responsibility due to greater directors' accountability}

All stakeholder models have the merit of putting the focus on the board. They increase its role as the defender of the company's interests, which implies a central place in corporate governance systems. Despite subtle differences between corporate governance models which have fueled rich and intensive discussions since the beginning of the twentieth century, all corporate governance stakeholders-oriented models appear to assume that the individual interest of the company should be respected as a specific interest. Although this approach posits the need to defend shareholders' interests, it promotes other interests corresponding to the company's need for sustainable profitability. Practice provides many examples, such as allowing the company to personally enter into binding contracts or be a party in litigation even if contrary to shareholders' interests consistent with the conception of the company as a 'legal entity'. Defining the precise scope of this interest remains challenging, however (Tirole 2005). Defining scope is relatively easy when the interests of the company

interests has been enshrined in statutory instruments and EU Regulations (see Chapter 2).

${ }_{14}$ 'A series of legal or voluntary obligations to which a company must adhere to be considered a model citizen in a given environment'. 
perfectly match with the sole shareholders' interest. When several interests are at stake, the board should arbitrate between them and prioritize them, given that it is difficult to find solutions that meet all interests. Compensation mechanisms can be put in place. For example, a company may want to offset some of the damage to the local environment by funding the building of a school, a clinic or a waste treatment facility (Tirole 2016). By doing so, it must make trade-offs that may not meet all interests. The board should answer questions such as: Where does the company's interest start and end? Which stakeholders should be included in its scope? Which interest prevails when divergent interests are at stake and how to balance them?

A major normative implication of the enlarged company interest is the central role of the board and its broader accountability. In support of broader stakeholder theory, Freeman highlighted the positive impact of broader directors' accountability and the need to balance stakeholders' competing interests (Freeman et al. 2007):

how critical it is for managers to consider in their decision-making process the interests and expectations of a broad and diverse set of stakeholders, rather than focus exclusively on the corporation's shareholders as previously argued by the agency logic: ties with key stakeholders may mitigate the likelihood of negative regulatory, legislative or fiscal action; attract socially conscious consumers; attract financial resources from socially responsive investors; enhance access to finance or help poorly performing firms to recover from disadvantageous positions more quickly; even may lead to better performance by protecting and enhancing corporate reputation.

Accordingly, the board of directors must be granted a crucial role and accorded great deference as an independent organ from the managers. According to the Communitarian model:

boards exist not to protect shareholders per se, but to protect the enterprisespecific investments of all the members of the corporate 'team' including shareholders, managers, rank and file employees, and possibly other groups, such as creditors. (Blair and Stout 1999)

The pluralist management model based on balancing all stakeholder interests requires a broad conception of board duties. Since corporate governance encompasses the relationship of the corporation to stakeholders other than shareholders, such as creditors, suppliers, customers or employees, the board's accountability naturally widens as directors are accountable not just to investors but also to other involved parties, i.e. employees, banks, suppliers, customers. These new expanded corporate governance duties of the board are reflected in increased accounting 
information, multiple reporting to the shareholders and other stakeholders and communications with the media, the public and civil society (see Part II). A great deal also depends on the way the business judgment rule is used and the different degrees to which courts defer to the business judgment of directors. Depending on jurisdictions, it may or may not give primacy to the boards' managerial expertise. It may or may not explicitly authorize directors to sacrifice shareholders' interest, for example, as in the Unocal test where a board of directors is authorized to prevent a takeover where it can be shown that there is a threat to corporate policy and the defensive measure adopted is proportional and reasonable given the nature of the threat (Unocal Corp. v. Mesa Petroleum Co. 1985)..$^{15}$ It may or may not defer to the board's judgment (see Part II).

The public conception of CSR increasingly accepts the idea that corporations are entities "with duties and responsibilities to the communities their behavior impacts' (Jackson 2011: 6) and that they are expected 'by society to serve some social purposes' (Jackson 2011: 7) thus increasing the scope of boards' responsibility. This new trend, however, conflicts with the traditional idea that the responsibilities of corporations and their representatives were solely those assigned to them by the laws of the countries in which they had operations. The view that voluntary self-regulation of multinational corporations may go beyond the legal domain has become common, as the Nike ${ }^{16}$ and Rana Plazza cases show. Academics gave early warning (Berle 1932; Tirole 2005; Dignam and Galanis 2009) about the risk inherent in expanding the powers and liability of managers, compared to their strictly limited scope under the shareholder theory. One might fear the outcome of the subsequent dilution of managerial accountability with boards fulfilling their role subject to less control. Under this enlarged director's primacy approach, the purpose of corporate governance is assumed to be driving directors to ensure compliance with the company's interests, as defined as its own and its various partners' interests. Boards are required to be efficient in many ways.

\footnotetext{
15493 A.2d 946 (Del. 1985).

16 Kasky v. Nike, Inc., no. S087859, 2 May 2002; Nike, Inc. v. Kasky, 539 U.S. 654 (2003).
} 


\section{BOX 1.1 NIKE v. KASKY}

In 1996, Nike was besieged with a series of allegations that it was mistreating and underpaying workers at foreign facilities. Nike responded to these charges in numerous ways and commissioned a report by former Ambassador to the United Nations Andrew Young that commented favourably on working conditions in the factories and found no evidence of widespread abuse or mistreatment of workers. In 1998, Marc Kasky sued Nike for unfair and deceptive practices under California's Unfair Competition Law and False Advertising Law. Kasky asserted that 'in order to maintain and/or increase its sales', Nike made a number of 'false statements and/or material omissions of fact' concerning the working conditions under which Nike products are manufactured.

Nike filed a demurrer to the complaint, contending that respondent's suit was absolutely barred by the First Amendment. The trial court sustained the demurrer without leave to amend and entered a judgment of dismissal. The California Court of Appeal affirmed, holding that Nike's statements 'form[ed] part of a public dialogue on a matter of public concern within the core area of expression protected by the First Amendment'. On appeal, the California Supreme Court reversed and remanded for further proceedings. The Court held that '[b]ecause the messages in question were directed by a commercial speaker to a commercial audience, and because they made representations of fact about the speaker's own business operations for the purpose of promoting sales of its products ... [the] messages are commercial speech'. (27 Cal. 4th 939, 946, 45 P.3d 243, 247 (2002).) The US Supreme Court granted certiorari to decide two questions: (1) whether a corporation participating in a public debate may 'be subjected to liability for factual inaccuracies on the theory that its statements are "commercial speech" because they might affect consumers' opinions about the business as a good corporate citizen and thereby affect their purchasing decisions'; and (2) even assuming the California Supreme Court properly characterized such statements as commercial speech, whether the 'First Amendment, as applied to the states through the Fourteenth, permit[s] subjecting speakers to the legal regime approved by that court in the decision below'. (Pet. for Cert. i.) The Court dismissed the writ of certiorari as improvidently granted. Later, Nike and Kasky agreed to settle the case for US\$1.5 million.

\section{(c) Long-term corporate goals should prevail over short-termism}

A financial corporate governance approach has, as its objective, easily predictable short-term profits. Director primacy requires a new, harder to achieve, approach which combines profit and performance. Such a long-term approach may conflict with the traditional goal of profit maximization as assigned to companies by corporate law. Additionally, doing social or societal good is costly. Reconciling short-term and long-term goals therefore remains challenging. Many theories which emerged in the 1990s were not successful in achieving such a reconciliation. Accordingly, whereas the proposition that business firms have 
social, environmental and human rights responsibilities was mostly uncontested, these objectives remained secondary to the economic performance imposed by shareholders (Tirole 2016). In the United States, where the dominant conventional management view remained that the primary moral and legal obligation of private sector managers was to maximize profits for shareholders and that corporations had no other obligations beyond those legally imposed by nation states, CSR was assumed to be limited to respecting obligations, laws and regulations in those states in whose jurisdictions the company was active. CSR actions were limited to compliance with the law and managers' primary obligation of maximizing profits was well established. The standard view relied on an underlying conflict between the profit maximization values of the market and human rights. At a time when, even in the United States, there was a growing dissatisfaction with the emphasis on short-term financial gain over long-term social welfare, the dominant ideology still held that companies that tried to operate under alternative models would be eliminated by competitors who were not so civic-minded (Jensen 2001: 16).

An important shift may originate in the law itself. Regulators may forbid actions on the basis of the precautionary principle or impose a duty to refrain from certain actions, such as limiting companies' investments and activities in the setting in which their activities have the potential to generate human rights risks which they do not have the resources to assess or mitigate. Law-makers may also choose to intervene in order to impose positive actions, such as requiring management to undertake credible environmental or human rights impact assessments, or requiring effective monitoring and reporting of corporate success measures in meeting its obligations. Rules of law which are created by international organizations must also be taken into account (UNGlobal Compact, Global Reporting Initiative (GRI), etc., see details in Millon, in Vasudev and Watson 2012: 76-7), which shows the progressive transformation into hard law of such soft law instruments (see further Chapter 2).

\subsection{CONCLUSION}

Corporate governance theories can be divided into two categories: (i) shareholder-oriented theories focused on how best to serve shareholders' interests, and (ii) stakeholder-oriented theories centered on how best to serve the community of interests impacted by corporate behaviour. Historically, corporate governance practice has long suffered a US 
bias reduced to a plain bipolar debate. Both approaches have their legal shortcomings and none are fully applied by any jurisdiction. In the aftermath of the global financial crisis a subtle pattern seems to have emerged in practice. Today, whether one considers that meeting ESG standards has a positive financial impact in the long run or that a company owes certain duties to society as a whole, companies have started to favour a long-term approach, further supporting the idea that adopting a long-term strategy is beneficial for companies. Determining this strategy is under the jurisdiction and responsibility of boards. The way such theories have been perceived by legal systems around the world is complex, as Chapter 2 will show. 